\title{
THE NEW DA'WAH STRATEGY AMONG MILLENNIAL GENERATIONS THROUGH TIKTOK DURING PANDEMIC
}

\author{
Fany Nur Rahmadiana Hakim ${ }^{1 *}$, Ihsan Kamaludin ${ }^{2}$, Shifa Nisrina Sujana ${ }^{3}$ \\ ${ }^{1}$ Gadjah Mada University, Yogyakarta, Indonesia,e-mail:fanybakim@mail.ugm.ac.id \\ ${ }^{2}$ Gadjah Mada University, Yogyakarta, Indonesia, e-mail:ihsankamaludin95@mail.ugm.ac.id \\ ${ }^{3}$ Garut University, West Java, Indonesia, e-mail:n.shifas123@gmail.com \\ *Corresponding Authors
}

\author{
cc) (i) (2) \\ (C)2021 by the authors. Submitted for possible open access publication under the terms and conditions of the Creative Commons \\ Attribution-ShareAlike 4.0 International License-(CC-BY-SA) (https://creativecommons.org/licenses/by-sa/4.0/) \\ doi) DOI : http://dx.doi.org/10.30983/islam realitas. $v 7 i 2.4756$ \\ \begin{tabular}{l|l|l} 
Submission: 8 September 2021 & Revised: 13 December 2021 & Published: 31 December 2021
\end{tabular}
}

\begin{abstract}
This research focuses on the strategy of public figures who develop religious content in order to spread religious values among the millennial generation, especially during the pandemic. The rampant use of the TikTok platform during the COVID-19 pandemic was not only deployed as an entertainment medium but was also used by many people to be able to spread propaganda and missions to disseminate religious values among the millennial generation. This is due to the popularity of that platform has skyrocketed, making some content creators and public figures develop the marketing of their ideological values on social media. By using the theory of social change and the concept of the development of communication, the authors try to analyze the phenomena that in question. This study uses a qualitative descriptive method with the TikTok application observation technique and seeks to explore various information in depth to find various facts that can explain this phenomenon. We also found that millennials who use the TikTok platform often start to look at various religious content and some are even active in filling the content because they are inspired by public figures who spread similar content. Moreover, some lecturers often provide religious information using music or duet features so as to encourage application users to spread religious teachings and share religious knowledge.
\end{abstract}

Keyword: New da'wah strategy, Millennial generation, TikTok, Pandemic

\begin{abstract}
Abstrak
Penelitian ini berfokus pada strategi tokoh masyarakat yang mengembangkan konten religi dalam rangka menyebarkan nilai-nilai agama di kalangan generasi milenial, terutama di masa pandemi. Maraknya penggunaan platform TikTok di masa pandemi COVID-19 tidak hanya dijadikan sebagai media biburan tetapi juga dimanfaatkan oleb banyak orang untuk bisa menyebarkan dakwab dan misi penyebarluasan nilai-nilai agama di kalangan generasi milenial. Hal ini dikarenakan popularitas platform tersebut yang meroket, membuat beberapa content creator dan public figure mengembangkan pemasaran nilai-nilai ideologisnya di media sosial. Dengan menggunakan teori perubahan sosial dan konsep perkembangan komunikasi, peneliti mencoba menganalisis fenomena yang terjadi. Penelitian ini menggunakan metode deskriptif kualitatif dengan teknik observasi aplikasi TikTok dan berupaya menggali berbagai informasi secara mendalam sehingga mampu menemukan berbagai fakta yang dapat menjelaskan fenomena tersebut. Kami juga menemukan bahwa generasi milenial yang menggunakan platform TikTok sering mulai melihat berbagai konten religi dan babkan ada yang aktif mengisi konten tersebut karena terinspirasi oleh tokoh masyarakat yang menyebarkan konten serupa. Apalagi beberapa dosen sering memberikan informasi agama dengan menggunakan fitur musik atau duet sehingga mendorong pengguna aplikasi untuk dapat menjalankan ajaran agama dan membagikan ilmu agama.
\end{abstract}

Kata Kunci: Strategi dakwah baru, Generasi millennial, TikTok, Pandemi

\section{Background}

TikTok is highly attractive for many internet users, especially millennials and 'gen z', this makes it as one of the most widespread platforms globally. Based on statistics, 
worldwide TikTok users currently reach more than 2 billion people, more than $75 \%$ of whom are active users. Of the many social media platforms, Tiktok is in the top 10 most used platforms. ${ }^{1}$ Most of the users are from America and Asia, and $80 \%$ of them are users who pay for subscriptions. ${ }^{2}$ One of the advantages is that it is integrated with other social media networks. ${ }^{3}$ By integrating with other social media, it is easier to share, so that content can quickly spread and be seen by many people. The average TikTok user is the young generation of productive age, ranging from teenagers to young adults aged 18-29 years. ${ }^{4}$ The average daily usage per person reaches 1 hour per day and the content produced by $80 \%$ of TikTok users is in the form of videos. ${ }^{5}$ Various types of content genres can be found easily in TikTok, such as pranks, beauty and make-up, dance and music, and so forth. These various content genres have been mapped into their respective audience markets.

By the development of a certain type of platform, there is an increase in public interest in the use of social media. In general, social media has become a tool that is inherent in the lives of young people. ${ }^{6}$ Moreover, it is available on a handy mobile phone that people can take it anywhere to update and post anything, anytime, and anywhere. Everyone's creativity is

1 Werner Geyser, 'TikTok Statistics - Revenue, Users \& Engagement Stats (2021)', Influencer Marketing Hub, 8 July 2021 <https://influencermarketinghub.com/tiktok-stats/>; Katie Sehl, '23 Important TikTok Stats Marketers Need to Know in 2021', Hootsuite, 5 May 2021 <https://blog.hootsuite.com/tiktok-stats/>; Wallaroo, 'TikTok Statistics - Updated June 2021', Wallaroo Media, 14 June 2021.

${ }^{2}$ Geyser.

3 Conney Stephanie, 'Jumlah Pengguna Aktif Bulanan TikTok Terungkap', Kompas.Com, 2021 <https://tekno.kompas.com/read/2021/04/19/14020 037/jumlah-pengguna-aktif-bulanan-tiktokterungkap?page $=$ all $>$.

${ }^{4}$ Sehl.

${ }^{5}$ Sehl. increasing, influenced by content that is easy to create with simple devices and concepts. ${ }^{7}$ People tend to get challenged to make the content as interesting as possible so that the content is in demand and enjoyed by many people. In addition, one of the goals of social media is to increase engagement. With increased engagement, there are benefits that may be obtained, including financial benefits as well as popularity gains. ${ }^{8}$ In addition, there are also people who use social media to share knowledge and information or other useful things. The knowledge that is usually shared is in the form of general knowledge, academic knowledge, to religious knowledge.

Discovering religious knowledge through digital media is now something compelling to many audiences. Apart from easier accessanywhere and anytime-, another reason why people turn to digital da'wah (conveying Islamic messages) is because of the innovation and creativity in the delivery, which has a direct personal impact. ${ }^{9}$ Nowadays, the form of da'wah is not only to convey about religious teachings and religious knowledge orally, but also in creative ways that can attract audiences. Social media, with its various features are more interesting for the younger generation. ${ }^{10}$ In the past, conventional da'wah was only from the pulpit. The congregation has limitations in

${ }^{6}$ Ibnu Hajar Sainuddin, 'Transformasi Dakwah di Masa Pandemi Covid-19', OSF Preprints, 2020, p. 1 <https://doi.org/10.31219/osf.io/nakhy>.

7 Xin Du and others, "I Want to Record and Share My Wonderful Journey": Chinese Millennials' Production and Sharing of Short-Form Travel Videos on 'TikTok or Douyin', Current Issues in Tourism, 2020, 1-13. <https://doi.org/10.1080/13683500.2020.1810212>.

${ }^{8} \mathrm{Du}$ and other.

9 Tinggal Purwanto, 'Digital Engagement of Indonesian Millennials in the Prism of the Scripture, Social Media, and Religious Practices', in AICIS (Jakarta: EAI, 2019), pp. 1-6 < https://doi.org/10.4108/eai.1-102019.2291735>.

10 Yohana Noni Bulele and Tony Wibowo, 'Analisis Fenomena Sosial Media dan Kaum Milenial: Studi Kasus Tiktok', Conference on Business, Social Sciences and Innovation Technology, 1.1 (2020), 565-72. 
interacting and communicating with the teacher. The monological nature of speeches is now considered boring because the congregation can only listen. It is rare for interactive communication to occur between preachers and audiences. Therefore, the lecturers continue to find alternatives and innovate to update their craft. Along with the development of technology, da'wah has begun to penetrate into electronic media such as radio and television. ${ }^{11}$ However, although conventional da'wah, electronic da'wah, and digital da'wah are each still in demand, the audience of the three is demographically different. Each method of da'wah has its own audiences, and usually, those who are interested in digital da'wah are millennials. ${ }^{12}$ Their interest in accessing digital-based da'wah is influenced by the intensity of their time using smartphones. The time they spend on social media tends to be more direct person-toperson interaction. ${ }^{13}$ With the pandemic, they will have even more time to network online and use their devices.

The COVID-19 pandemic has changed people's communication habits in many aspects. Various sectors have turned to virtual settings, especially for non-essential sectors. A lot of restrictions imposed by the government limit the physical mobility of people; however, they do not limit creativity. ${ }^{14}$ It may be that people's boredom during a pandemic with all its protocols have given birth to new innovations and have allowed them to be more productive in producing content, including da'wah content. This paper will describe how

11 Awaludin Pimay and Fania Mutiara Savitri, 'Dinamika Dakwah Islam di Era Modern', Jurnal Ilmu Dakwah, 41.1 (2021), 43-55 ; H. M. Nafis, 'Transformasi Sosial dan Dakwah di Era Milenium III', Teologia, 16.2 (2005), 1-14.

12 Yedi Purwanto, Muhamad Taufik, and Asep Wawan Jatnika, 'Peran Teknologi Informasi dalam Perkembangan Dakwah Mahasiswa', Jurnal Sosioteknologi, 16.1 (2017), 94-109; Retna Dwi Estuningtyas, 'Strategi Komunikasi dan Dakwah Pada Kalangan Milenial di Era the transformation of da'wah that follows the development of information technology by utilizing social media. Tiktok is the platform chosen to be studied using qualitative methods. The framework used to analyze is the theory of social change which is combined with the concept of development of communication. Initial findings show that during the pandemic, TikTok has attracted enough Muslim millennials to consume da'wah content presented by preachers who use online means as their new da'wah strategy.

\section{Shifting from Conventional to Digital}

The diverse expression of da'wah in digitalized and computerized information technology can be categorized as new media. This has allowed people to access religious teachings on major problems in human life. This has been a major influence on religious life, including theological problems, shifts in morality, and psychological problems. Scholars have argued that the habits of people on social media who carry religious narratives, especially in the form of da'wah, are attempts to answer the problems mentioned above through a new pattern of media consumption. New media helps renew da'wah, making it more able to reach people from various walks of life. For many Islamic scholars, da'wah must be actual, factual, and contextual, because it must be able to adapt to the conditions in society according to its era. Diversity, in this sense, refers to the different modes of communication without losing the substance of what is conveyed. Digitization of da'wah is a sign that Islamic teachings are able to adapt to the times and

Modernisasi', Muttaqien, 2.1 (2021), 75-86 ; Mohammad Rindu Fajar Islamy, 'Optimalisasi Dakwah Media Sosial di Kalangan Mahasiswa di Masa Pandemi dalam Dimensi Globalisasi', Jurnal Dakwah dan Komunikasi, 6.1 (2021), 4. 13 Hanifah Islamiyah, 'Pengaruh Intensitas Menggunakan Tik Tok terhadap Perilaku Body Shaming Anak', Orasi: Jurnal Dakwah dan Komunikasi, 11.2 (2020), $205<$ https://doi.org/10.24235/orasi.v11i2.6640>. ${ }^{14}$ Sainuddin. 
technology. Religious actors must be able to deliver da'wah in an innovative way in line with developments and needs in society without compromising the quality of the essence of the content of the da'wah. ${ }^{15}$ Da'wah in the digital world provides an alternative delivering the religious messages and developing scholarly pursuits. $^{16}$

One concept related to the digitalization of da'wah is the 'living Quran', which is media campaign to bring the Quran into daily life. This is targeted towards the young generation, since they use many digital platforms to practice Islamic teachings including memorizing, reciting, learning, and understanding the Quran. The living Quran is the implementation of its by adjusting to the social and cultural context. The attitudes of millennial Muslims toward the Quran depend on how the Quran itself influences them, since it is considered as the main reference for living. Even though its teachings are learned virtually, people could feel the soulful impact from the Quran for its 'living' character. In explaining the living Quran, Purwanto (2019) classifies it into three, living Quran in writing, in oral tradition, in religious practices. In writing and the oral tradition, he mainly talks about the textual scripture shared on social media. Meanwhile, in the religious practices, he divides it into da'wah, political, and medical. He concludes that the living Quran is a part of the millennial Muslim response toward the development of digital technology to keep the Quran alive despite the changing media. ${ }^{17}$

15 Afidatul Asmar, 'Ekspresi Keberagaman Online: Media Baru dan Dakwah', Jurnal Ilmu Dakwah, $40.1 \quad$ (2020), 54-64 <https://doi.org/10.21580/jid.v40.1.5298>; Arman Syah Putra, 'Peran Sosial Media Sebagai Media Dakwah di Zaman Pandemic Virus Corona Atau Covid 19 di Indonesia', Panangkaran: Jurnal Penelitian Agama dan Masyarakat, 4.1 (2021), 88-97.

${ }^{16}$ Kurniati Abidin and Rasyidah Zainuddin, 'The Virtual Dakwah in Pandemic Covid-19 Era', Palakka:
Beside the positive outcome of performing da'wah in digital platforms, there are also problems that arise when da'wah enters the digital realm which can cause its original values to be degraded. There are three issues that have become the focus of scholar, the first is regarding the need to offer an interpretation of the scripture that is sensitive to contemporary socio-political issues. There is also the issue of the capitalization of da'wah in the current digital era. Finally, there is the issue of polarization of religious teachings, whereby many Muslim preachers have become proactive, polemical, and display unprofessional conduct. The audience's reinterpretation of scripture which is called mad'u has become a problem, since not everyone has the requisite knowledge to interpret scripture. ${ }^{18}$ This is also related to another problem, namely the growing number of Muslim preachers on social media tend to have more knowledge of business strategies to gain material benefits and fame, rather than deep religious knowledge. Thus, capitalistic goals by paying attention to market demand has become a problem that deserves attention. The term da'wah in digital media has been referred to 'cyberda'wab' and 'da'wabtainment. In this model, da'wah has become more preoccupied with socio-political issues, rather than the spiritual concern. ${ }^{19}$

\section{Da'wah and the Pandemic}

The current Covid-19 pandemic is also one of the factors that has led to the increasingly massive da'wah movement through various digital media. With the

Media and Islamic Communication, 1.2 (2020), 149-58 $<$ https://mail.jurnal.iain-

bone.ac.id/index.php/palakka/article/view/1124>.

17 Purwanto.

18 Abidin and Zainuddin, p. 151; Aris Risdiana, Reza Bakhtiar Ramadhan, and Imam Nawawi, 'Transformasi Dakwah Berbasis "Kitab Kuning" Ke Platform Digital', Jurnal Lektur Keagamaan, 18.1 (2020), 1$28<$ https://doi.org/http://doi.org/10.312 $91 /$ jlk.v18i1.682>.

${ }^{19}$ Risdiana, Ramadhan, and Nawawi. 
minimization of physical activities, such as meetings and direct interactions between people, the intensity of the use of technology that relies on virtual space has increased dramatically. ${ }^{20}$ With such health protocols related to the pandemic, religious preachers are looking for alternatives to spread Islamic teachings widely to the public. The use of online platforms in carrying out da'wah aims to prevent the spread of the COVID-19. ${ }^{21}$ Moreover, religious preachers as agents of da'wah can also be protected from viruses and the public would still receive benefits from da'wah. ${ }^{22}$ Thus, the pandemic has not stopped da'wah activities but has shifted its form to get more intense in digital media.

\section{The Concept of Da'wah and Its Dynamics}

Before we discuss the new da'wah strategy in the pandemic era, we have to agree first on what is the definition of Islamic propagation, whic is widely known as da'wah. Many scholars have defined da'wah - in a broader contextas an invitation or call for Muslims to carry out religious ordinances and do good to one another. ${ }^{23}$ The definition presented here uses the broader context because it is acceptable by most people, including young Muslims. With that unspecified method of delivering Islamic teachings, one can have their own way in performing da'wah. By design, it is a very dynamic activity. This is influenced by sociocultural developments that are in line with technological developments. People's needs and expectations continue to evolve and the

20 Abidin and Zainuddin.

21 Nur Kumala Dewi and Arman Syah Putra, 'Efektivitas E-Dakwah Dengan Menggunakan Aplikasi Zoom di Masa Pandemic Corona Virus (COVID 19)', Seminar Nasional Kaburipan, 2020, 207-201.

22 Dewi and Putra; Putra.

${ }^{23}$ Nurdin Nurdin, 'To Dakwah Online or Not to Dakwah Online: Da'i Dilemma in Internet Age', $\mathrm{Al}$ Misbah, $\quad 10.1 \quad$ (2014), 21-34 $<$ http://almishbahjurnal.com/index.php/almishbah/article/view/34>; Fadly Usman, 'Efektivitas Penggunaan Media Online Sebagai Sarana Dakwah', media used will also continue to get more advanced. ${ }^{24}$ However, some preachers still try to maintain a method of da'wah that is in accordance with conventional methods. ${ }^{25}$ There are also those who adjust to the demands of the audience who want da'wah in a way that is not boring and tends to have more impact, especially for young Muslims.

The online da'wah has seen major growth, since it is not limited by space and time. Both as preachers and audiences, many people tend to prefer virtual interactions to learn about religious knowledge. Many preachers today hold Islamic and Quranic learning programs online. $^{26}$ The purpose is probably because of convenience. This is supported by the public's need for information acceleration due to the transforming communication styles and technology. ${ }^{27}$ The changes in the method of da'wah from conventional to modern methods do not reduce the essence of the knowledge conveyed. However, there is still the potential that the values are reduced during the process.

\section{Social Change}

Social changes which include the digitization of media have an impact on shifting the role of the media that are becoming more personal. The impact of the convergence and divergence of personal media has led to the emphasis on the functions of presentation, interaction, and archiving. ${ }^{28}$ The four functions have their respective roles, although, in reality, we can see that these functions are obscured

Jurnal Ekonomi dan Dakwah Islam (Al-Tsiqoh), 1.01 (2016), 1-8 ; Purwanto, Taufik, and Jatnika.

${ }^{24}$ Nafis.

${ }^{25}$ Nurdin.

${ }^{26}$ Fatimah Husein and Martin Slama, 'Online Piety and Its Discontent: Revisiting Islamic Anxieties on Indonesian Social Media', Indonesia and the Malay World2, 46.134 (2018), 80-93 <https://doi.org/10.1080/13639811.2018.1415056>.

${ }^{27}$ Purwanto, Taufik, and Jatnika.

28 Terje Rasmussen, Personal Media and Everyday Life: A Networked Lifeworld (London: Palgrave Macmillan, 2014), p. 10. 
because of the bias that causes each of these functions to be distinguished.

Rasmussen has described the relationship of personal media in relation to social change as follows,

"The view here is that personal media enhance particular forms of social change in modern society, and that they both accelerate certain changes and compensate for roads not taken. This has always been the case with media technologies-what is new is that these forms of social regulation have reached the private realms of the individual in a fundamental way." 29

The shift in the nature of media to become more personal is in line with people's lifestyles. This is included in the category of the "communication revolution" which has made the community more participatory because it triggers interaction in the media in the form of cultural products, digital multimedia, and information services. ${ }^{30}$ These changes do not pay attention to material-based matters that are oriented towards the economy. Instead, people need a communication style that is more suited to a fast-paced and easy-to-use lifestyle.

Seeing its relation to religion, social change is closely associated with ritual processions. In religion, rituals are important and are often carried out continuously by their adherents. From a sociological perspective, rituals have a function to strengthen solidarity in society. ${ }^{31}$ Therefore, the media of da'wah can go through different rituals according to habits and developments in society.

\footnotetext{
${ }^{29}$ Rasmussen.

30 Paschal Preston, Reshaping Communication: Technology, Information and Social Change (London: SAGE Publication, 2001), p. 6.

${ }^{31}$ Rasmussen.

32 Jody Waters, 'Power and Praxis in Development Communication Discourse and Method', in Redeveloping Communication for Social Change (Lanham: Rowman \& Littlefield Publishers, Inc, 2000), pp. 89-102.
}

\section{Development of Communication}

Da'wah methods which are now starting to shift to the digital realm, especially social media, can be said to be influenced by popular culture. This popular culture can be not only a means of entertainment that can affect people's lifestyles, but also can have an important role as the conveyers of important information from various sectors to the community. Another advantage is that the information can reach various levels of society, as explained by Freire (1970) that:

"New approaches emphasized how communication and information could be used by marginalized people to investigate and articulate their own needs, solutions, and strategies and thus enhance their abilities to engage in social transformation." 32

In this sense, the development of communication can be said to have a close correlation with social change. Many scholars agree that there is a role for communication that directly impacts social change because of the intertwining that is also linked to culture. ${ }^{33}$ Communication that continues to develop is always able to produce and modify the way of life of society although some only see it as an organizational delivery system.

"The transformation from the traditional to the modern society required greater functional specialization and structural differentiation. These structural changes brought about value shifts in the direction of individualism, secularism, universalism, and rationalism.",34

In addition, if we look at the arguments above, it can be said that social changes that

33 H. Leslie Steeves, 'Gendered Agendas: Dialogue and Impasse in Creating Social Change', in Redeveloping Communication for Social Change (Lanham, 2000), pp. 7-26; Srinivas Raj Melkote and H. Leslie Steeves, Communication for Development: Theory and Practice for Empowerment and Social Justice, third (India: SAGE Publication, 2015), p. 6.

${ }^{34}$ Melkote and Steeves. 
have implications for structural changes encourage a shift in the direction of communication between humans.

\section{Factors Driving Teens to Use TikTok during the Pandemic}

The use of social media platforms such as TikTok during the pandemic has increased significantly, especially since the implementation of large-scale social restrictions in Indonesia began to be implemented. ${ }^{35}$ This is because activities of society are starting to be limited, especially social interaction in public spaces. This has led to massive changes in various aspects of people's lifestyles. The education sector also felt a significant impact, especially the students and teachers, who usually attend and interact in schools and are now meeting online. ${ }^{36}$

Distance learning that is carried out at home also makes them confused about fulfilling their various goals and maintaining good habits, especially for students and teachers who are used to interacting a lot with their peers to exchange information or support their respective hobbies. ${ }^{37}$ This also encourages them to look for other alternative ways so that they can channel their various hobbies and preferences. One of them is by using the TikTok platform, this is not only because the platform provides a variety of information and entertainment that can distract them from boredom but they can also express their emotions and conditions in a popular way

${ }^{35}$ Adam Rizal, 'Diunduh 1 Miliar Kali, Pengguna TikTok Melonjak Selama Pandemi Corona', Infokomputer, 2020.

36 Pengelola Web Kemdikbud, 'Penyesuaian Keputusan Bersama Empat Menteri Tentang Panduan Pembelajaran di Masa Pandemi COVID-19', Kemdikbud, 2020 .

${ }^{37}$ Agia Dwi Visi Utami, Suci Nujiana, and Dasrun Hidayat, 'Aplikasi Tiktok Menjadi Media Hiburan bagi Masyarakat dan Memunculkan Dampak Ditengah Pandemi Covid-19', Medialog: Jurnal Ilmu Komunikasi, 4.1 (2021), 40-47 <https://doi.org/10.35326/medialog.v4i1.962>; Fany so that the audience is expected to better understand the various things being conveyed. ${ }^{38}$

Although the use of the TikTok platform does not cover various age groups, its popularity makes the platform one of the main media platforms. In 2020 alone, its users have exceeded 2 billion. ${ }^{39}$ This also makes many activists or public figures see TikTok as an opportunity to spread their popularity in society. TikTok's mission to inspire people to be more creative and have fun has allowed people to entertain users while educating them. $^{40}$ TikTok makes it easy for users to create videos where movement and music are fundamental. The focus of the content is more on short videos so that people can get the information they want effectively. On the other hand, this short arrangement also allows content creators to upload various creative content in a short time which will increase the person's popularity.

The increasing popularity of the use of the TikTok platform among the public is supported by various features and content that can cover various aspects of life. ${ }^{41}$ What is more, the International version of the TikTok platform targets teenagers or young people as their main market share who incidentally are among those who use gadgets the most and have various social media accounts to connect

Rachma, 'Dinamika Pembelajaran Daring di Tengah Pandemi Covid-19', Beritamagelang, 2020.

38 Salsabila Aulia, 'Aplikasi Tiktok Dapat Memberikan Manfaat Bagi Penggunanya', Kumparan, 2020.

${ }^{39}$ Iwan Supriatna, 'TikTok Raup Hampir 2 Miliar Pengguna, Kalahkan Medsos Lainnya', Suara.Com, 2021.

40 Ageng Wuri, 'Manjakan Pengguna Baru, TikTok Indonesia Berikan Konten Hobi Yang Lebih Beragam', Gadgetren, 2020.

41 Juan Carlos Medina Serrano, Orestis Papakyriakopoulos, and Simon Hegelich, 'Dancing to the Partisan Beat: A First Analysis of Political Communication on Tik'Tok', Websci' 20, 6.10 (2020). 
with their peers. ${ }^{42}$ The provision of sharing features to other platforms also makes it easier for users to spread their content to various social media accounts. Thus, teenagers feel that the various content they post can reach a larger audience. The sharing feature that TikTok users use also encourages content creators to be more creative and varied so that the message conveyed in the video can be understood or even imitated in everyday life. The millennial generation who actively uses TikTok also often tries to form a certain trend so that other users can follow, they usually take advantage of certain duet or tutorial features such as contemporary dances and life hacks that can simplify their daily lives. ${ }^{43}$

\section{The Implementation of Digital Da'wah during the Pandemic}

The Covid-19 pandemic is still happening in Indonesia, this pandemic first entered Indonesia in the middle of $2020{ }^{44}$ Various policies were implemented to break the chain of the virus's transmission. ${ }^{45}$ One of the government's policies in this regard is to instruct the public to reduce social interaction and maintain distance and implement health protocols that prevent the transmission of the Covid-19 virus such as masks, disinfectants, and others. ${ }^{46}$

With the implementation of these rules, it is necessary that various activities such as work

42 Katie Elson Anderson, 'Getting Acquainted with Social Networks and Apps: It Is Time to Talk about TikTok', Library Hi Tech News, 2020 <https://doi.org/10.1108/LHTN-01-2020-0001>.

${ }^{43}$ Rifan Aditya, 'Cara Duet di TikTok, Ikut Tren Challenge Hingga Nyanyi Bareng', Suara.Com, 2021.

44 Nurul Jannah and Lailatul Fitria, 'Implementation Of Work From Home And Work from Office with Online Absence As An E-Government Implication In New Normal', Civil Service, 14.1 (2020), 69-84.

45 Ilham Akhsanu Ridlo, 'Tantangan Kebijakan Kesehatan Mental Indonesia di Masa Pandemi', Fkm.Unair.Ac.Id, 2020.

46 Rahmat Riadi, 'Strategi Penangan Bencana Non-Alam Covid-19 dalam Pemilihan Serentak 2020', and teaching and learning both in schools and universities are subject to restrictions. ${ }^{47}$ This has forced some workplaces and schools to shift from a face-to-face system to online (networks) by using supporting platforms such as Zoom, Youtube, WhatsApp, and others. ${ }^{48}$ Not only that, the existence of these restrictions has closed several shops, entertainment venues, and non-health public facilities (other than the health sector). Thus, residents tend to use social media and the internet on smartphones which can be reached by the majority of the community and can make it easier for people to interact or just seek entertainment to fill their spare time when the restrictions are imposed. This shows that social can change people's lifestyles especially during the current pandemic. ${ }^{49}$ Social media, such as Instagram, Telegram, Line, TikTok are used as a means of interacting with friends, parents, and others as well as facilitating users to share ideas, work together, and build community. ${ }^{50}$

The existence of social media and other platforms is the impact of rapid technological developments in this modern era of globalization. Social media can be utilized in various aspects of life, one of which is progress in various social aspects which makes communication between users faster and easier. Social media also provides many features ranging from sharing photos to videos.

Electoral Governance Jurnal Tata Kelola Pemilu Indonesia, 2.2 (2021), 141-61.

47 Sekretariat GTK, 'Pendidikan Era New Normal: Belajar dari Study From Home', Gtk Kemdikbud, 2020.

48 Muhyiddin, 'Covid-19, New Normal dan Perencanaan Pembangunan di Indonesia Covid-19', The Indonesian Journal of Development Planning, 4.2 (2020), 24052.

49 Machyudin Agung Harahap and Susri Adeni, 'Tren Penggunaan Media Sosial Selama Pandemi di Indonesia', Jurnal Professional FIS UNIVED, 7.2 (2020), 13-23.

${ }^{50}$ Estuningtyas. 
One of the social media that is currently loved by the Indonesian people, especially during social restrictions during the Covid-19 pandemic, is the TikTok platform. ${ }^{51}$ This platform from China was launched in 2016 by Zhang Yiming and entered Indonesia in 2016. ${ }^{52}$ This platform is one of the platforms that concentrate more on sharing videos along with supporting features to record, add or create sounds, add stickers, filters, and even has itsk own editing system. ${ }^{53}$ The emergence of various video editing platforms with their own uniqueness can be seen from the large number of video content scattered on various social media originating from various countries, one of which is Indonesia itself.

However, in 2018 the TikTok platform was once banned. This was due to the many negative reports from the public regarding the platform. On July 3, 2018, TikTok was officially blocked by the Ministry of Communication and Information (Kominfo) ${ }^{54}$ Reports for TikTok to be blocked did not only come from Kominfo, but Kominfo also admitted that the proposal to block TikTok also came from the Ministry of Women's Empowerment and Child Protection (PPPA), the Indonesian Child Protection Commission (KPAI), and from other layers of society. ${ }^{55}$

Samuel Pangerapan said that TikTok was considered negative for children due to content violations on TikTok related to pornography, immorality, to religious abuse. ${ }^{56}$ The Minister of Communication and Informatics, Rudiantara explained that the blocking was due to a large number of negative contents,

\footnotetext{
${ }^{51}$ Utami, Nujiana, and Hidayat.

52 Admin PMB LIPI, 'Pandemi, TikTok, Dan Media Edukasi', Pmb.Lipi.Go.Id, 2021.

53 Islamiyah.

54 admin, 'Kominfo: Blokir Tik Tok Hanya Sementara', Kominfo. Go.Id, 2018.

${ }_{55}$ Bulele and Wibowo.

56 Viska, 'Banyak Alasan di Balik Buka Tutup Blokir Tik Tok', Kominfo.Go.Id, 2018.
}

especially for children, as Kominfo has coordinated with the Ministry of KPAI and PPPA. However, the blocking of the TikTok platform was only temporary. In August 2018 the platform was reopened. ${ }^{57}$ The opening of this platform is carried out with consideration and various new regulations, one of which is by limiting the age of users starting from the age of 13 (thirteen) years. ${ }^{58}$

The videos that were widely made by teenagers at that time were trend-following content, such as imitating the movements of TikTokers accompanied by certain music, choreographers, music videos, and challenges. ${ }^{59}$ These impersonations are sometimes not sorted out beforehand, resulting in the creation of content that is not worthy of being viewed or shown widely. Most of them are willing to do anything for the sake of popularity and to increase their TikTok account followers. In addition, the tendency of TikTok users who do everything they can to get followers and likes from other users is one of them by looking vulgar. It is the tendency that makes some educators and religious leaders concerned about the negative impact of the TikTok platform because the minimum age limit is loose, so it is possible for children under the age of eleven to access it. ${ }^{60}$

Behind the negative side of the TikTok platform, the positive impacts of TikTok are also many, such as a means to display talents such as singing, painting, making music, dancing, and even sharing insights on many things such as health, education, culture, business, to religious content such as da'wah

${ }^{57} \mathrm{CNN}$ Indonesia, 'Alasan Kominfo Blokir Tik Tok’, Cnnindonesia.Com, 2018.

${ }^{58}$ Daon001, 'Tik Tok Dilarang untuk Pengguna Usia di Bawah 13 Tahun', Kominfo.Go.Id, 2018.

59 Admin PMB LIPI.

${ }^{60}$ Trie Damayanti and Ilham Gemiharto, 'Kajian Dampak Negatif Aplikasi Berbagi Video dagi AnakAnak di Bawah Umur di Indonesia', Communication, 10.1 (2019),

<https://doi.org/10.36080/comm.v10i1.809>. 
and Quranic recitation. The rise of negative content that had caused TikTok itself to be blocked has motivated some people to shift the positive side of TikTok with useful content, one of which is making this platform a means of da'wah or sharing videos containing religious content.

In addition, the current pandemic conditions require the closure of mosques, prayer rooms, Islamic boarding schools, and taklim assemblies (non-formal educational institutions that concentrate on religious knowledge) for the study of religious knowledge which are usually routinely carried out by the community. Meanwhile, during the lockdown periode, social and religious strengthening was needed. ${ }^{61}$ Communication and da'wah are an inseparable part of Islam. The dynamics that occur between preachers (religious leaders) and recipients of da'wah usually occur from several aspects, one of which is preaching. Da'wah is basically an activity to call or invite someone to believe in Allah by increasing spiritual values based on the Quran and Sunnah (hadith). The goal is to form a strong personality and commendable morals. ${ }^{62}$ Currently the media and methods of da'wah are increasingly diverse, one of which is through the TikTok platform. The widespread use of TikTok is currently being used by some Muslims in Indonesia to increase religious insight and da'wah activities.

Globalization requires the da'i or preachers to always keep up with the times, especially technological changes that have an impact on the increasingly diverse mass media. ${ }^{63}$ Usually, da'wah is carried out directly in assemblies. However, these assemblies can be reached only by certain people because it can only be obtained in certain places. Through social

${ }^{61}$ Ridwan Lubis and others, Dinamika Aktivitas Keagamaan di Masa Pandemi, ed. by Lukmanul Hakim and Ismail, 1st edn (Jakarta: Litbangdiklat Press, 2020), p. 169.

${ }^{62}$ Islamy. media, this has changed. Social media can be accessed anytime and anywhere has made it easier for those who want to share their religious knowledge to meet those who are looking for religious knowledge. The pattern of spreading da'wah which is increasingly widespread is also the impact of the internet. Da'wah media through online methods is currently in great demand by the public in the form of studies, lectures, and series. In addition, the da'wah video content can be repeated continuously indefinitely as long as the uploader does not delete the content, which is one of the advantages of da'wah with social media.

The millennial generation is one of the generations targeted by this TikTok propaganda media because the users of this platform are dominated by teenagers. Not only da'wah content, content containing videos of the Quran, Islamic motivations are also widely found in the platform. The rise of da'wah content on TikTok shows that the existence of da'wah on the platform is recognized and much-loved, especially by teenagers. In line with Deni's statement that the da'wah content on TikTok is more targeted at the millennial generation's, at least there are alternative contents that they can enjoy other than content that only features music or dance. ${ }^{64}$

The existence of da'wah on the TikTok platform can be seen in how many ustadz or clerics (Islamic religious leaders) create accounts and content on this platform, such as Ustadz Syam, Husain Basyaiban, Hamzali Abradinezad, Yudhi Darmawan, Noval Down, Habib Ja'far and other. Not only content from accounts that are managed directly by the ustadz or ustadzah (religious leader) themselves, but religiously nuanced content is also often

63 Pimay and Savitri.

${ }^{64}$ Deni Mardiana, (Teacher, MA Persis Tarogong) Interview, \{Friday 16 June 2021\} 
created by other accounts that share lecture or motivational content from a video of a religious leader from the platform such as YouTube, television, or videos from the science council. For instance, we have the TikTok account with the name@Teman.Paradise with over 65.5000 followers which contains da'wah content from cleric Oki Setiana Dewi who in fact does not have a TikTok account.

This means that the dissemination of da'wah content on this platform is not limited only to religious leaders, people who care about religion also try to share content that is useful. Thus, a lot of information and religious insights are disseminated and strengthened by influencers. This was occurring even before the limitations imposed by the Covid-19 pandemic. Before the TikTok platform existed, the media that was often used to spread da'wah content was through radio, YouTube, Instagram, WhatsApp. Of course, with various da'wah media, there are differences in the delivery because each social media has its own features.

Nontheless, since TikTok limits duration or length of videos that can be uploaded, the depth and range of the religious discussions are not also limited compared to in person meetings. The majority of the da'wah discussion on TikTok is simple, which is precisely what makes millennials interested, Helma, one of our informants, said that with a short duration is actually suitable for users who are mostly young people, so a short but clear explanation will be effective compared to tens of minutes on YouTube or television which tend to be boring. ${ }^{65}$

However, there are also those who think that the short duration results in a discrepancy between what is conveyed and what the audience understands, as Septiani explained.

65 Helma Mardiana, (High School Student), Interview, \{Saturday 17 July 2021\}

66 Septiani, (Student) Interview, \{Friday 16 July $2021\}$
The content of TikTok's da'wah may be referred to as advice. Nevertheless, a study of religious knowledge must be accompanied by a clear and detailed explanation to avoid confusion. Hence, he claims that he prefers to watch videos on YouTube or come directly to the assembly. ${ }^{66}$ With short-duration content on TikTok, influencers often upload videos with many parts (sections) or are segmented. Some people are even more interested in this format because they are driven by curiosity to see the next part. Huaida said that if you watch a lot of content part, you actually want to see and explore more about the content. ${ }^{67}$

But some people think that the TikTok platform has more negative impacts. As Masnun said, she thought that the negative impacts of TikTok outweighed the benefits, so it is better to leave it. However, the good and bad impacts of the platform depend on each user. Carefully choosing content will have a good impact on the individual. In line with Alifa's opinion that while the positive and negative sides of TikTok depend on the TikTok account owner, the negative side is that people follow the trending songs and dances, which are considered indecent by Muslim standards. Despite that, on the positive side there are also some TikTok account users who make inspiring videos about religion, education, and others. ${ }^{68}$

\section{Conclusion}

Before the pandemic came, TikTok had become one of the social media widely used by millennials in Indonesia. A variety of content is created on TikTok and each genre has its own audience. Over time, educational and positive themes have also been noticed by content creators, including young preachers who began to enliven and give color to the content themes

68 Alifa Annisa Rahma, (Student) Interview, \{Saturday 17 July 2021\} 
on TikTok. When the pandemic came, the intensity of posting and content creation has become even more massive. People who are getting distressed of restrictions during the pandemic have more fun to lingering with their gadgets and enjoying the content on various media, especially TikTok. This phenomenon is relevant to the theory of social change which explains the shift in people's habits that correspond to technological developments. With digitalized da'wah, people feel that messages are conveyed more personally than conventional da'wah. In line with this, the concept of development of communication also has a similar argument. Digital da'wah engagement will reach a wider audience. A typical modernized society, tend to choose what is easier, more attractive, and more accessible for them to do. Doing da'wah through TikTok is currently seen as something that appeals to people, particularly those who feel trapped and unstimulated during the pandemic situation.

\section{References}

Abidin, Kurniati, and Rasyidah Zainuddin, 'The Virtual Dakwah in Pandemic Covid19 Era', Palakka: Media and Islamic Communication, 1.2 (2020), 149-58 $<$ https://mail.jurnal.iainbone.ac.id/index.php/palakka/article/vi ew/1124>

Aditya, Rifan, 'Cara Duet di TikTok, Ikut Tren Challenge hingga Nyanyi Bareng', Suara.Com, 2021

admin, 'Kominfo: Blokir Tik Tok Hanya Sementara', Kominfo.Go.Id, 2018

Admin PMB LIPI, 'Pandemi, TikTok, dan Media Edukasi', Pmb.Lipi.Go.Id, 2021

Anderson, Katie Elson, 'Getting Acquainted with Social Networks and Apps: It Is Time to Talk about TikTok', Library Hi Tech NewS, 2020 $<$ https://doi.org/10.1108/LHTN-012020-0001>
Asmar, Afidatul, 'Ekspresi Keberagaman Online: Media Baru dan Dakwah', Jurnal Ilmu Dakwah, 40.1 (2020), 54-64 <https://doi.org/10.21580/jid.v40.1.529 $8>$

Aulia, Salsabila, 'Aplikasi Tiktok Dapat Memberikan Manfaat Bagi Penggunanya', Kumparan, 2020

Bulele, Yohana Noni, and Tony Wibowo, 'Analisis Fenomena Sosial Media dan Kaum Milenial: Studi Kasus Tiktok', Conference on Business, Social Sciences and Innovation Technology, 1.1 (2020), 565-72

CNN Indonesia, 'Alasan Kominfo Blokir Tik Tok', Cnnindonesia.Com, 2018

Conney Stephanie, 'Jumlah Pengguna Aktif Bulanan TikTok Terungkap', Kompas.Com, 2021

<https://tekno.kompas.com/read/2021 /04/19/14020037/jumlah-penggunaaktif-bulanan-tiktokterungkap?page $=$ all $>$

Damayanti, Trie, and Ilham Gemiharto, 'Kajian Dampak Negatif Aplikasi Berbagi Video bagi Anak-Anak di Bawah Umur di Indonesia', Communication, 10.1 (2019), 1 $<$ https://doi.org/10.36080/comm.v10i1 $.809>$

Daon001, 'Tik Tok Dilarang untuk Pengguna Usia di Bawah 13 Tahun', Kominfo.Go.Id, 2018

Dewi, Nur Kumala, and Arman Syah Putra, 'Efektivitas E-Dakwah dengan Menggunakan Aplikasi Zoom di Masa Pandemic Corona Virus (COVID 19)', Seminar Nasional Kahuripan, 2020, 2072011

Du, Xin, Toni Liechty, Carla A Santos, and Jeongeun Park, “I Want to Record and Share My Wonderful Journey": Chinese Millennials' Production and Sharing of Short-Form Travel Videos on TikTok or Douyin', Current Issues in Tourism, 2020, 1 13

<https://doi.org/10.1080/13683500.202 $0.1810212>$

Estuningtyas, Retna Dwi, 'Strategi Komunikasi 
dan Dakwah pada Kalangan Milenial di Era Modernisasi', Muttaqien, 2.1 (2021), 75-86

Geyser, Werner, 'TikTok Statistics - Revenue, Users \& Engagement Stats (2021)', Influencer Marketing Hub, 8 July 2021 $<$ https://influencermarketinghub.com/ti ktok-stats $>$

GTK, Sekretariat, 'Pendidikan Era New Normal: Belajar dari Study from Home', Gtk Kemdikbud, 2020

Harahap, machyudin agung, and Susri Adeni, 'Tren Penggunaan Media Sosial Selama Pandemi di Indonesia', Jurnal Professional FIS UNIVED, 7.2 (2020), 13-23

Husein, Fatimah, and Martin Slama, 'Online Piety and Its Discontent: Revisiting Islamic Anxieties on Indonesian Social Media', Indonesia and the Malay World2, $46.134 \quad$ (2018), 80-93 <https://doi.org/10.1080/13639811.201 $8.1415056>$

Islamiyah, Hanifah, 'Pengaruh Intensitas Menggunakan Tik Tok terhadap Perilaku Body Shaming Anak', ORASI: Jurnal Dakwah dan Komunikasi, 11.2 (2020), 205 <https://doi.org/10.24235/orasi.v11i2.6 $640>$

Islamy, mohammad rindu fajar, 'Optimalisasi Dakwah Media Sosial di Kalangan Mahasiswa di Masa Pandemi dalam Dimensi Globalisasi', Jurnal Dakwah dan Komunikasi, 6.1 (2021)

Jannah, Nurul, and Lailatul Fitria, 'Implementation of Work From Home And Work From Office with Online Absence As An E-Government Implication In New Normal', Civil Service, 14.1 (2020), 69-84

Kemdikbud, Pengelola Web, 'Penyesuaian Keputusan Bersama Empat Menteri Tentang Panduan Pembelajaran di Masa Pandemi COVID-19', Kemdikbud, 2020

Lubis, Ridwan, Ismail, Marpuah, Daniel Rabitha, Fikriyah Malihah, Sahrani, and others, Dinamika Aktivitas Keagamaan di Masa Pandemi, ed. by Lukmanul Hakim and Ismail, 1st edn (Jakarta pusat: Litbangdiklat Press, 2020)

Melkote, Srinivas Raj, and H. Leslie Steeves, Communication for Development: Theory and Practice for Empowerment and Social Justice, third (India: SAGE Publication, 2015)

Muhyiddin, 'Covid-19, New Normal dan Perencanaan Pembangunan di Indonesia Covid-19', The Indonesian Journal of Development Planning, 4.2 (2020), 240-52

Nafis, H. M., 'Transformasi Sosial dan Dakwah di Era Milenium III', Teologia, 16.2 (2005), 1-14

Nurdin, Nurdin, 'To Dakwah Online or Not to Dakwah Online: Da'i Dilemma in Internet Age', Al Misbah, 10.1 (2014), 2134

$<$ http://almishbahjurnal.com/index.php /al-mishbah/article/view/34>

Pimay, Awaludin, and Fania Mutiara Savitri, 'Dinamika Dakwah Islam di Era Modern', Jurnal Ilmu Dakwah, 41.1 (2021), 43-55

Preston, Paschal, Reshaping Communication: Technology, Information and Social Change (London: SAGE Publication, 2001)

Purwanto, Tinggal, 'Digital Engagement of Indonesian Millennials in the Prism of the Scripture, Social Media, and Religious Practices', in AICIS (Jakarta: EAI, 2019), pp. 1-6 <https://doi.org/10.4108/eai.110-2019.2291735>

Purwanto, Yedi, Muhamad Taufik, and Asep Wawan Jatnika, 'Peran Teknologi Informasi dalam Perkembangan Dakwah Mahasiswa', Jurnal Sosioteknologi, 16.1 (2017), 94-109

Putra, Arman Syah, 'Peran Sosial Media Sebagai Media Dakwah di Zaman Pandemic Virus Corona Atau Covid 19 di Indonesia', Panangkaran: Jurnal Penelitian Agama dan Masyarakat, 4.1 (2021), 88-97

Rachma, Fany, 'Dinamika Pembelajaran Daring di Tengah Pandemi Covid-19', Beritamagelang, 2020

Rasmussen, Terje, Personal Media and Everyday Life: A Networked Lifeworld (London: 
Palgrave Macmillan, 2014)

Riadi, Rahmat, 'Strategi Penangan Bencana Non-Alam Covid-19 dalam Pemilihan Serentak 2020', Electoral Governance Jurnal Tata Kelola Pemilu Indonesia, 2.2 (2021), 141-61

Ridlo, Ilham Akhsanu, 'Tantangan Kebijakan Kesehatan Mental Indonesia di Masa Pandemi', Fkm.Unair.Ac.Id, 2020

Risdiana, Aris, Reza Bakhtiar Ramadhan, and Imam Nawawi, 'Transformasi Dakwah Berbasis "Kitab Kuning" ke Platform Digital', Jurnal Lektur Keagamaan, 18.1 (2020), $1-28$ <https://doi.org/http://doi.org/10.312 91/jlk.v18i1.682>

Rizal, Adam, 'Diunduh 1 Miliar Kali, Pengguna TikTok Melonjak Selama Pandemi Corona', Infokomputer, 2020

Sainuddin, Ibnu Hajar, 'Transformasi Dakwah di Masa Pandemi Covid-19', OSF Preprints, 2020

<https://doi.org/10.31219/osf.io/nakhy $>$

Sehl, Katie, '23 Important TikTok Stats Marketers Need to Know in 2021', Hootsuite, 5 May 2021 $<$ https://blog.hootsuite.com/tiktokstats $/>$

Serrano, Juan Carlos Medina, Orestis Papakyriakopoulos, and Simon Hegelich, 'Dancing to the Partisan Beat: A First Analysis of Political Communication on
TikTok', Websci' 20, 6.10 (2020)

Steeves, H. Leslie, 'Gendered Agendas: Dialogue and Impasse in Creating Social Change', in Redeveloping Communication for Social Change (Lanham, 2000), pp. 7-26

Supriatna, Iwan, 'TikTok Raup Hampir 2 Miliar Pengguna, Kalahkan Medsos Lainnya', Suara.Com, 2021

Usman, Fadly, 'Efektivitas Penggunaan Media Online Sebagai Sarana Dakwah', Jurnal Ekonomi dan Dakwah Islam (Al-Tsiqob), 1.01 (2016), 1-8

Utami, Agia Dwi Visi, Suci Nujiana, and Dasrun Hidayat, 'Aplikasi Tiktok Menjadi Media Hiburan Bagi Masyarakat dan Memunculkan Dampak di Tengah Pandemi Covid-19', Medialog: Jurnal Ilmu Komunikasi, $4.1 \quad$ (2021), 40-47 $<$ https://doi.org/10.35326/medialog.v4i $1.962>$

Viska, 'Banyak Alasan di Balik Buka Tutup Blokir Tik Tok', Kominfo.Go.Id, 2018

Wallaroo, 'TikTok Statistics - Updated June 2021', Wallaroo Media, 14 June 2021

Waters, Jody, 'Power and Praxis in Development Communication Discourse and Method', in Redeveloping Communication for Social Change (Lanham: Rowman \& Littlefield Publishers, Inc, 2000), pp. 89102

Wuri, Ageng, 'Manjakan Pengguna Baru, TikTok Indonesia Berikan Konten Hobi yang Lebih Beragam', Gadgetren, 2020 